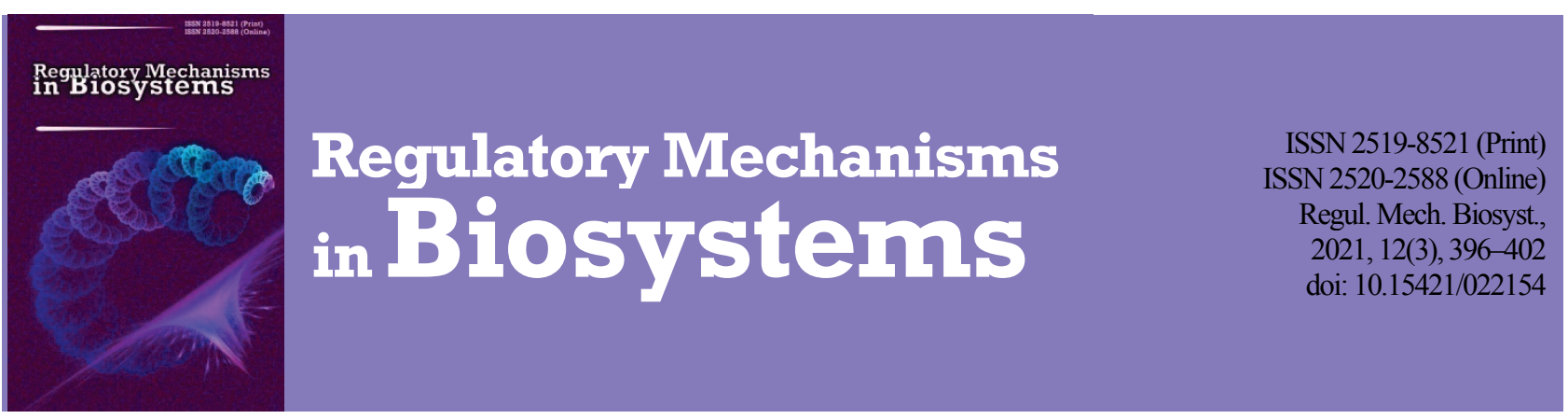

\title{
Content and location of lymphocyte subpopulations with markers CD4+, CD8+ and CD20+ in the esophageal tonsil of chickens and the Meckel diverticulum of ducks
}

\author{
V. T. Khomich*, N. V. Dyshliuk*, T. A. Mazurkevych*, S. V. Guralska**, S. I. Usenko* \\ *National University of Life and Environmental Sciences of Ukraine, Kyiv, Ukraine \\ **Polissia National University, Zhytomyr, Ukraine
}

Article info

Received 27.06.2021 Received in revised form 02.08 .2021

Accepted 03.08.2021

National University of Life and Environmental Sciences of Ukraine, Heroyivoboronyst., 15/3, Kyiv, 03041, Ukraine. Tel: + 38-067-712-02-67 E-mail:dushlyuk@ukr.net

Polissia National

University,

Stary Boulevard, 7

Zhytomyr, 10002, Ukraine

Tel: $+38-050-285-81-10$

E-mail:guralska@ukr.net

\begin{abstract}
Khomich, V. T., Dyshliuk, N. V., Mazurkevych, T. A., Guralska, S. V., \& Usenko, S. I. (2021). Content and location of lymphocyte subpopulations with markers $\mathrm{CD} 4+, \mathrm{CD} 8+$ and $\mathrm{CD} 20+$ in the esophageal tonsil of chickens and the Meckel diverticulum of ducks. Regulatory Mechanisms in Biosystems, 12(3), 396-402. doi:10.15421/022154
\end{abstract}

Immune formations of birds' digestive organs, including the esophageal tonsil and Meckel's diverticulum, protect the body from foreign antigens that enter the body with food and water and play an important role in maintaining the genetic constancy of its internal environment. This unique property of the immune system is formed during ontogenesis and is associated with maintaining the selection of lymphocyte clones that are able to respond to foreign antigens and carry out a specific immune response of two types: humoral and cellular. This article presents the results of a study of T- and B-lymphocyte subpopulations of the esophageal tonsil of Shever 579 cross chickens at the age of 25 , 180 and 300 days, the Meckel diverticulum of the Blagovarsky cross ducks at the age of 30, 150 and 180 days. Immunohistochemical and statistical research methods were used to determine the localization and quantitative parameters of cell populations of lymphocytes (CD4+, $\mathrm{CD} 8+, \mathrm{CD} 20+$ ) using monoclonal antibodies and the DAKO EnVision FLEX+ imaging system (Dako Cytomation, Denmark). Separate subpopulations of T-lymphocytes (CD4+ - helpers, CD8+-cytotoxic / T-suppressors) and mature B-lymphocytes (CD20+) were found in the esophageal tonsil and Meckel diverticulum of birds. Their presence confirms that antigen-independent proliferation and differentiation of lymphocytes into effector cells occur in the immune formations of the digestive system. The lymphoid tissue of these formations is represented mainly by a well-defined diffuse form and nodules with light centers (secondary). In the esophageal tonsil of chickens, these structures are located in the tunica mucosa and tela submucosa, and in the Meckel diverticulum of ducks - also in the tunica muscularis. The content of lymphocytes with these markers predominates in diffuse lymphoid tissue compared to that in secondary lymphoid nodules. In the diffuse lymphoid tissue of the esophageal tonsil, lymphocytes are located mainly near the adenomeres and excretory ducts of the esophageal glands, blood vessels, and under the surface epithelium, and in Meckel's diverticulum - around the crypts, in their epithelium and in the epithelium of the villi. They are also found in the light centers of lymphoid nodules and on their periphery. The indices of the content of lymphocytes with the indicated markers in the esophageal tonsil and Meckel diverticulum which we determined were associated with age characteristics of the poultry in the postnatal period of ontogenesis. According to our observations, the content of CD20+ lymphocytes was the highest, while the populations of CD4+ and CD8+ lymphocytes were much smaller. This indicates an increase in the activity and predominance of the humoral immunity over the cellular one. The content of CD20+ lymphocytes was highest in birds at the age of 180 days, that is, during their sexual maturity. The data presented in the work can be used by morphologists researching the organs of the immune system, immunologists, poultry specialists involved in breeding, using and raising poultry and in educational work.

Keywords: immunohistochemistry; lymphocyte markers; humoral immunity; cellular immunity; foreign antigens.

\section{Introduction}

Currently, industrial poultry farming is the most dynamic branch of the agro-industrial complex of Ukraine, which in a short time has managed to increase production and provide the population with high quality meat and egg products. The development of poultry farming and its prospects in increasing the volume of products require significant attention from morphologists to carrying out the necessary comprehensive studies of the structure and dynamics of development of all systems and apparatus of the body, including the digestive apparatus of poultry in order to prevent diseases, as well as effective treatment, and improvement of the nonspecific immunity of the body, so as to obtain high quality food (Polegenka, 2019).

Due to the absence of the Pirogov-Waldeyer pharyngeal lymphoid ring in birds, which is present in mammals, the walls of their tubular digestive organs contain significant accumulations of lymphoid tissue that forms the basis of immune formations, including the esophageal tonsil and Meckel's diverticulum (Branton, 1988; Besoluk, 2001). They are part of the peripheral organs of hematopoiesis and lymphopoiesis (Nagy et al., 2005; Kovtun \& Kharchenko, 2009). The esophageal tonsil of birds is located in the area of transition of the caudal (thoracic-abdominal) part of the esophagus to the glandular part (proventriculus) of the stomach. It is visible macroscopically in the form of a folded, tuberous with irregular edges of a whitish strip against the background of the tunica mucosa. This location of the esophageal tonsil is anatomically determined by and closely related to the longitudinal folds of the esophagus (Khomych et al., 2020). Meckel's diverticulum of birds, officially called diverticulum vitellinum, is a duct of the yolk sac that connects it to the lumen of the jejunum and has the form of a tube with a narrowed apex (Gofur, 2020).

Immune formations of the digestive system are among the first to respond to the action of antigens that enter the body with food and water. As a result, they carry out a specific immune response of two types: humoral and cellular (Gofur, 2020). It is believed that the goal of humoral immunity is to remove antigenic exogenous substances from the body mainly, whereas the cellular immunity eliminates autoantigens, which may be its own mutating and denatured cells (Sharma, 1991; Fellah et al., 
2014). The leading cells that carry out immunological surveillance are lymphocytes (Koutsos \& Klasing, 2014). They are specialized cells that are able to respond only to a separate group of structurally similar antigens. The body's ability to respond to almost any antigen is due to the presence of a significant number of different groups and clones of lymphocytes. Lymphocytes differ not only in the specificity of their receptors, but also in functional properties. According to the latter, there are two main classes of lymphocytes: T-lymphocytes and B-lymphocytes (Rahman et al., 2001; Kaspers \& Göbel, 2016). The process of their formation is antigenic and occurs for T-lymphocytes in the thymus and B-lymphocytes in the bursa of Fabricius of birds (Ciriaco, 2003; Karadag, 2015; Oliyar et al., 2020). Under the influence of microenvironmental factors and as a result of genetic variability of the genome regions responsible for the molecular organization of the variable part of the cellular receptor, Tand B-lymphocytes acquire specific receptors to foreign antigens on their surface. They migrate to the peripheral organs of hematopoiesis and lymphopoiesis.

Migration allows each individual lymphocyte clone, which is specific to a particular antigen, to meet with it. In the peripheral organs of hematopoiesis and lymphopoiesis, there occurs their antigen-dependent proliferation and differentiation into effector cells that provide specific immunity (Jeurissen et al., 1989; Yasuda et al., 2003). The proliferation is preceded by the blast transformation of lymphocytes. Several types of subpopulation cells occur after the proliferation of blast-transformed T-lymphocytes. T-killers (cytotoxic) destroy foreign target cells and provide the genetic constancy of the internal environment of the body, protecting it from invasion of foreign cells, neoplasms, autoimmune diseases. T-helpers are involved in the processes of intercellular cooperation with B-lymphocytes, without which the transformation of B-lymphocytes into plasma cells is impossible. T-suppressor cells block antibody production by B-lymphocytes in autoimmune reactions. Plasma cells, which are effector cells of Blymphocytes, produce immunoglobulins from which antibodies are constructed. Antibodies are able to bind and neutralize antigens that have entered the body (Donmez et al., 2012; Oláh et al., 2013; Logvinova et al., 2020).

Deeper understanding of the lymphoid tissue functions of the immune formations of the digestive organs of poultry requires exact knowledge of the composition of populations of their lymphocytes (Casteleyn, 2010; Dishluk \& Orlova, 2010; Samour, 2015). Therefore, the aim of our study was to determine the content and features of the topography of CD4+, $\mathrm{CD} 8+$ and CD20+ lymphocytes in the norm to obtain data on their composition in the esophageal tonsil of chickens and Meckel's diverticulum of ducks of different ages.

\section{Materials and methods}

Selection of birds for the research, the study protocols, euthanasia of the birds were approved by the local ethics committee of the National University of Life and Environmental Sciences of Ukraine. The birds were maintained, fed, and took care of according to the principles formulated in the European Convention for the Protection of Vertebrate Animals used for Experimental and Other Scientific Purposes (Strasburg, March 18, 1986, ETS No. 123) and the order No. 3447-IV as of 21.02.2006 "On protection of animals against abuse" and the Provisions of the "European convention for the protection of animals used for experimental and other scientific purposes" (Ukraine).

The anatomical level of the study included: slaughter and exsanguination of poultry; opening the thoracic and abdominal cavities; preparation of the esophagus in the area of its transition to the glandular part (proventriculus) of the stomach of chickens and the jejunum of ducks, followed by their removal from the cavities. Poultry were slaughtered by the method of acute exsanguination after ether anesthesia.

Immunohistochemical studies were performed in the laboratory of pathomorphology CSD HEALTH CARE (Kyiv). Material for research (esophageal tonsils of chickens and Meckel's diverticulum of ducks) was taken from clinically healthy chickens of the Shever 579 cross at the age of 25,180 and 300 days and the Blagovarsky cross ducks aged 30, 150 and 180 days. To detect lymphocytes and their effector cells in the lymphoid tissue of the esophageal tonsil and Meckel's diverticulum of ducks, we used the immunohistochemical method. For this purpose, in histological sections, using monoclonal antibodies (Dako Cytomation, Denmark) and imaging systems DAKO EnVision FLEX + (Dako Cytomation, Denmark), we detected subpopulations of lymphocytes expressing antigenic markers of CD4+ cells (Thelpers), CD8+ (T-cytotoxic / T-suppressors) and $\mathrm{CD} 20+$ (mature B-lymphocytes).

The immunohistochemical study protocol included the following steps. The material was fixed in a $10 \%$ aqueous solution of buffered neutral formalin for 24 hours in order to preserve the integrity of cells and tissues, since fixation in acidic formalin often causes damage to antigenic determinants with the subsequent impossibility of carrying out immunohistochemical reactions. After rinsing, the material was dehydrated with ethanol and embedded in highly purified paraffin with polymer additives (Richard-Allan Scientific, USA) at a temperature no higher than $+60^{\circ} \mathrm{C}$. From paraffin blocks, on a Microm HM325 rotary microtome, tissue sections with a thickness of $5 \mu \mathrm{m}$ were made, which were placed on glass slides and stained using standard techniques with hematoxylin and eosin (Kaltek, Italy). For further immunohistochemical studies, the sections were mounted on poly-L-lysine-coated slides or Super Frost Plus slides (Menzel, Germany) and left overnight in a thermostat at $+37^{\circ} \mathrm{C}$, or for 30 minutes in a thermostat at $+56{ }^{\circ} \mathrm{C}$. To unmask tissue antigens, the method of heat treatment of sections in Target Retrieval Solution High $\mathrm{pH}$ buffer (Dako Cytomation, Denmark) was used by treatment in PT Modul (Dako Cytomation, Denmark) for $32 \mathrm{~min}$ at the temperature of $+98 \ldots+99^{\circ} \mathrm{C}$, taking into account the recommendations of the antibody manufacturer. After blocking non-specific protein binding by a protein block (Diagnostic Biosystems, USA) and endogenous peroxidase activity by a peroxidase block (Diagnostic Biosystems, USA), primary antibodies were applied. Visualization of primary antibodies was performed using the detection system DAKO EnVision FLEX + (Dako Cytomation, Denmark). To visualize the histological structure of the test tissue, the treated immunohistochemicals were additionally stained with Mayer's hematoxylin for 1-3 min (Dako Cytomation, Denmark) and covered with balm or Faramount Aqueous Mounting Medium (Dako Cytomation, Denmark). They were studied using an Olympus microscope $(\times 200, \times 400$, $\times 1000$ ), and the peculiarities of location and content of cells were determined with different types of markers. To count the cells that express the markers, we used histological sections in 10 randomly selected fields of view of the microscope (per conditional unit of area, at the magnification of $\times 400$ ). Microphotography of histological specimens was performed using a digital camera attached to a Primo Star microscope (Carl Zeiss, Germany) and connected to a personal computer.

The obtained results of the studies were recorded, and their digital indicators were processed statistically using the StatSoft Statistica 13.1 (2016) software, taking into account the specifics of statistical methods in biomedical research (Avtandilov, 1990; Goralskyy et al., 2015). The data are presented in the tables as $\mathrm{x} \pm \mathrm{SD}$ (standard deviation). Differences between the values in different age groups were determined using the Tukey test, where the differences were considered reliable at $\mathrm{P}<0.05$ (with taking into account Bonferroni correction).

\section{Results}

Content and distribution of lymphocytes subpopulations in the lymphoid tissue of esophageal tonsil of chickens aged 25, 180 and 300 days. Significant accumulations of lymphoid tissue were located in the folds of the tunica mucosa and tela submucosa of the esophageal tonsil of chickens of the studied groups. It contained a well-developed diffuse form and nodules with light (germinative) centers. The response to the identification of subpopulations of lymphocytes that express the antigenic markers CD4+, CD8+ and CD20+ in these forms of lymphoid tissue was positive and the cells containing the corresponding protein had a characteristic brown colour with a clear contour of the contrast-colored envelope.

Using monoclonal antibodies CD4+, we identified T-helpers. They were found locally in diffuse lymphoid tissue near the adenomeres of the esophageal glands and in the epithelium of their excretory ducts, as well as around the blood vessels (Fig. 1a). These cells were located in a chain in the form of a circle on the lymphoid nodules' periphery under the connective tissue membrane and were less often detected in their central zone 
(Fig. 1b). These lymphocytes were also seen between epithelial cells in the stratum basale and the lower rows of the stratum spinosum of the superficial epithelium and below it.

As is known, monoclonal antibodies CD8+ express T-cytotoxic cells / T-suppressors. These single cells or their small clusters are recorded in diffuse lymphoid tissue. In separate lymphoid nodules (at one of the poles), these cells formed crescent-shaped chains directly under the membrane (Fig. 1c, d).

A large amount of B-lymphocytes was found in the esophageal tonsil of chickens using monoclonal antibodies with the CD20+ marker. They were distributed diffusely, or in small clusters in the lamina propria of the tunica mucosa and the tela submucosa of this esophagus part, around the glands adenomeres and their excretory ducts, blood vessels, and somewhat less in the lymphoid nodules (Fig. 1e, f). In the latter, CD20+ lymphocytes were found diffusely at their periphery and in the center. Separate marker cells were found in the glandular epithelium of the esophageal glands and in their lumens.

The content of subpopulations of lymphocytes expressing markers CD4+, CD8+ and CD20+ in diffuse lymphoid tissue was slightly higher than in secondary lymphoid nodules of the esophageal tonsil in chickens of all studied groups and depended on the age of the bird (Table 1).

The content of CD4+ lymphocytes in the esophageal tonsil of chickens was insignificant. It increased in diffuse lymphoid tissue from 25 to 300 days of age (by $70.3 \%$ ). This increase was most intense from 25 to 180 days (by $56.0 \%$ ) and least intense from 180 to 300 days (by $9.2 \%$ ). In lymphoid nodules, a significant content of CD4+-lymphocytes was recorded in chickens aged 180 days. Compared with 25-day days old individuals, this indicator increased by $10.2 \%$, and by $14.2 \%$ compared with 300 days-old individuals. The content of lymphocytes expressing the CD8+ marker in the esophageal tonsil of chickens of all ages was slightly lower than previous marker cells (CD4+ lymphocytes). Their number in diffuse lymphoid tissue also increased from 25 to 300 days of age of the bird (by 53.1\%). The content of CD8+ lymphocytes increases unevenly, the most intensive growth occured from 25 to 180 days (by 33.4\%), and slightly slowed down from 180 to 300 days (by 14.7\%). In secondary lymphoid nodules, a significant content of cells with the marker CD8+, as well as CD4+ lymphocytes, was recorded in 180 days-old chickens. Compared with 25 -day days, this indicator increased by $28.4 \%$, and with 300-day days - by $11.9 \%$.

CD20+ lymphocytes were best expressed in the esophageal tonsil of chickens, their content being the greatest in the diffuse lymphoid tissue and lymphoid nodules of birds at the age of 180 days. The content of CD20+ lymphocytes increased by $33.5 \%$ and $35.5 \%$, respectively, com- pared with 25 -day ones, and by $22.4 \%$ and $18.4 \%$, respectively, with 300 day lymphocytes.

Content and distribution of lymphocyte subpopulations in the Meckel diverticulum of ducks at the age of 30,150 and 180 days. Lymphoid tissue of Meckel's diverticulum was morpho-functionally matured, located in the tunica mucosa, tela submucosa and tunica muscularis in ducks of all studied groups. As in the esophageal tonsil of chickens, the diffuse form and secondary lymphoid nodules were better expressed in it as well. Lymphoid tissue of Meckel's diverticulum of ducks contained lymphocytes that expressed markers CD4+, CD8+ and CD20+. On histological specimens, using monoclonal antibodies, these cells also had a distinctive brown colour, different topography and content.

Lymphocytes expressing the CD4+ marker in the Meckel's diverticulum of ducks were found locally in the diffuse lymphoid tissue around the crypts and in the germinal centers of the lymphoid nodules (Fig. 2a). Separate lymphocytes with this marker locally infiltrate the epithelium of villi and crypts. Lymphoid nodules with CD4+ lymphocytes were located in parallel to the bundles of smooth muscle cells in the tunica muscularis. They were located one by one or in groups (packages) - from two or more. There were more lymphocytes expressing the CD8+ marker, like the previous cells, in the lymphoid tissue of the Meckel diverticulum of ducks of the studied age groups in the diffuse lymphoid tissue than in the lymphoid nodules. CD8+ lymphocytes were mainly located diffusely or in the form of chains in the fibrous connective tissue of the lamina propria, between crypts, and also in the tela submucosa. In the lymphoid nodules of the tunica mucosa and tunica muscularis, these cells were predominantly localized in their central areas and a small amount appeared on the periphery of the nodules in the mantle zone (Fig. 2b, c).

The population of lymphocytes expressing the CD20+ marker in the Meckel diverticulum of ducks of all ages was the largest (Fig. 2d). These cells were quite densely distributed in the diffuse lymphoid tissue between the lymphoid nodules and around the crypts. They were also detected in the superficial epithelium and crypt epithelium. In the secondary lymphoid nodules of the tunica mucosa and tunica muscularis, CD20+ lymphocytes were distributed less densely throughout their area, mainly in the germinal centers. Compared to CD20+ cells of the germinal center, in the mantle (peripheral) zone of nodules their content was slightly lower, as well as the level of expression of this immunohistochemical marker.

The content of CD4+, CD8+ and CD20+ in the Meckel diverticulum of ducks of different age groups in diffuse and nodular forms of lymphoid tissue varied. Moreover, according to our observations, the number of lymphocyte subpopulations with these markers was greater in diffuse lymphoid tissue than in lymphoid nodules (Table 2).

Table 1

The content of lymphocytes subpopulations in the esophageal tonsil of chickens per conditional unit of area $(x \pm S D, n=4)$

\begin{tabular}{cccccc}
\hline \multirow{2}{*}{$\begin{array}{c}\text { Age of chickens, } \\
\text { days }\end{array}$} & \multicolumn{3}{c}{ Diffuse lymphoid tissue } & \multicolumn{2}{c}{ Secondary lymphoid nodules } \\
\cline { 2 - 6 } & CD4+ & CD8+ & CD20+ & CD4+ & CD8+ \\
\hline 25 & $22.8 \pm 1.10^{\mathrm{a}}$ & $12.2 \pm 0.70^{\mathrm{a}}$ & $126.3 \pm 2.18^{\mathrm{a}}$ & $14.8 \pm 0.97^{\mathrm{a}}$ & $8.9 \pm 0.52^{\mathrm{a}}$ \\
180 & $35.6 \pm 0.91^{\mathrm{b}}$ & $16.3 \pm 0.77^{\mathrm{b}}$ & $168.6 \pm 1.77^{\mathrm{b}}$ & $22.3 \pm 1.38^{\mathrm{b}}$ & $11.4 \pm 0.66^{\mathrm{b}}$ \\
300 & $38.9 \pm 2.06^{\mathrm{b}}$ & $18.7 \pm 0.82^{\mathrm{b}}$ & $130.7 \pm 1.39^{\mathrm{c}}$ & $19.1 \pm 1.22^{\mathrm{b}}$ & $146.4 \pm 2.46^{\mathrm{b}}$ \\
\hline
\end{tabular}

Note: different letters indicate the values significantly differ from the another age group in the column of Table 1 on the results of comparison using the Tukey test $(\mathrm{P}<0.05)$ with Bonferroni correction.

Table 2

The content of subpopulations of lymphocytes in the Meckel's diverticulum of ducks per conventional unit area $(\mathrm{x} \pm \mathrm{SD}, \mathrm{n}=4)$

\begin{tabular}{|c|c|c|c|c|c|c|}
\hline \multirow{2}{*}{$\begin{array}{c}\text { Age of ducks, } \\
\text { days }\end{array}$} & \multicolumn{3}{|c|}{ Diffuse lymphoid tissue } & \multicolumn{3}{|c|}{ Secondary lymphoid nodules } \\
\hline & CD4+ & CD8+ & CD20+ & CD4+ & CD8+ & CD20+ \\
\hline 30 & $12.3 \pm 0.79^{\mathrm{a}}$ & $26.4 \pm 0.95^{\mathrm{a}}$ & $67.1 \pm 0.72^{\mathrm{a}}$ & $8.8 \pm 0.67^{\mathrm{a}}$ & $9.4 \pm 0.72^{\mathrm{a}}$ & $24.5 \pm 1.34^{\mathrm{a}}$ \\
\hline 150 & $33.7 \pm 0,93^{\mathrm{a}}$ & $29.1 \pm 0.80^{\mathrm{a}}$ & $97.7 \pm 0.88^{\mathrm{a}}$ & $23.1 \pm 0.64^{\mathrm{a}}$ & $15.4 \pm 0,70^{\mathrm{b}}$ & $30.4 \pm 0.87^{\mathrm{b}}$ \\
\hline 180 & $40.2 \pm 0.92^{\mathrm{b}}$ & $37.0 \pm 1.34^{\mathrm{b}}$ & $111.5 \pm 2.76^{\mathrm{b}}$ & $32.2 \pm 1.09^{\mathrm{a}}$ & $25.5 \pm 1.59^{\mathrm{c}}$ & $37.9 \pm 1.05^{\mathrm{c}}$ \\
\hline
\end{tabular}

Note: see Table 1 .

The content of lymphocytes expressing the marker CD4+ in diffuse lymphoid tissue and lymphoid nodules of Meckel's diverticulum of ducks was quite insignificant. The highest content of these cells was recorded in the 180-day-old birds. Compared with 30-day-old ducks, this indicator increased by $226.8 \%$ in diffuse lymphoid tissue and $265.9 \%$ in secondary lymphoid nodules. The increase in CD4+ lymphocytes occured unevenly and was more intense in ducks from 30 to 150 days in diffuse lymphoid tissue (173.9\%) and lymphoid nodules (162.5\%) - and less intense this process occurred in these structures in birds aged 150 to 180 days (by $19.2 \%$ and $39.3 \%$, respectively).

The content of CD8+ lymphocytes in the Meckel's diverticulum of 30-day-old ducks was also insignificant. In birds from 30 to 180 days of age in diffuse lymphoid tissue, the increase in the content of these cells occurred less intensely (by $40.1 \%$ ), while in lymphoid nodules their signi- 
ficant increase was observed (by $171.3 \%$ ). The increase in the content of CD8+ lymphocytes in the diffuse lymphoid tissue and lymphoid nodules of the Meckel diverticulum of ducks occurred unevenly from days 30 to 150 (by $10.2 \%$ and $63.8 \%$, respectively) and from days 150 to 300 (by $27.1 \%$ and $65.5 \%$, respectively). Lymphocytes expressing the marker $\mathrm{CD} 20+$ were found in largest amounts in ducks of all studied groups.
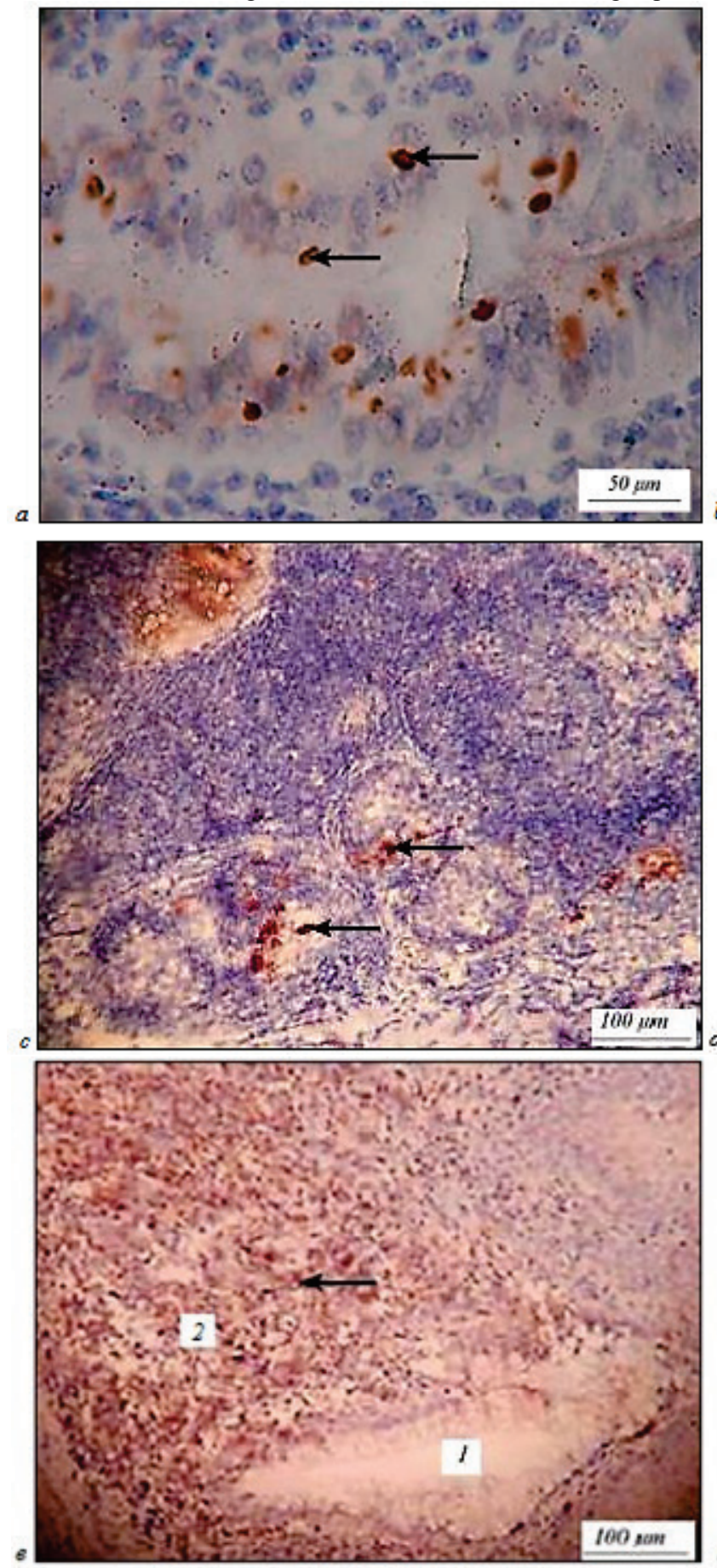

The content of these cells increased with the age of the ducks. In diffuse lymphoid tissue, the content of CD20+ lymphocytes from 30 to 180 days of age increased by $66.2 \%$ (from 30 to 150 days - by $45.6 \%$ and from 150 to 180 days - by $14.1 \%$ ), and in secondary lymphoid nodules - by $54.6 \%$ (from 30 to 150 days - by $24.1 \%$ and from 150 to 180 days - by $24.6 \%)$.
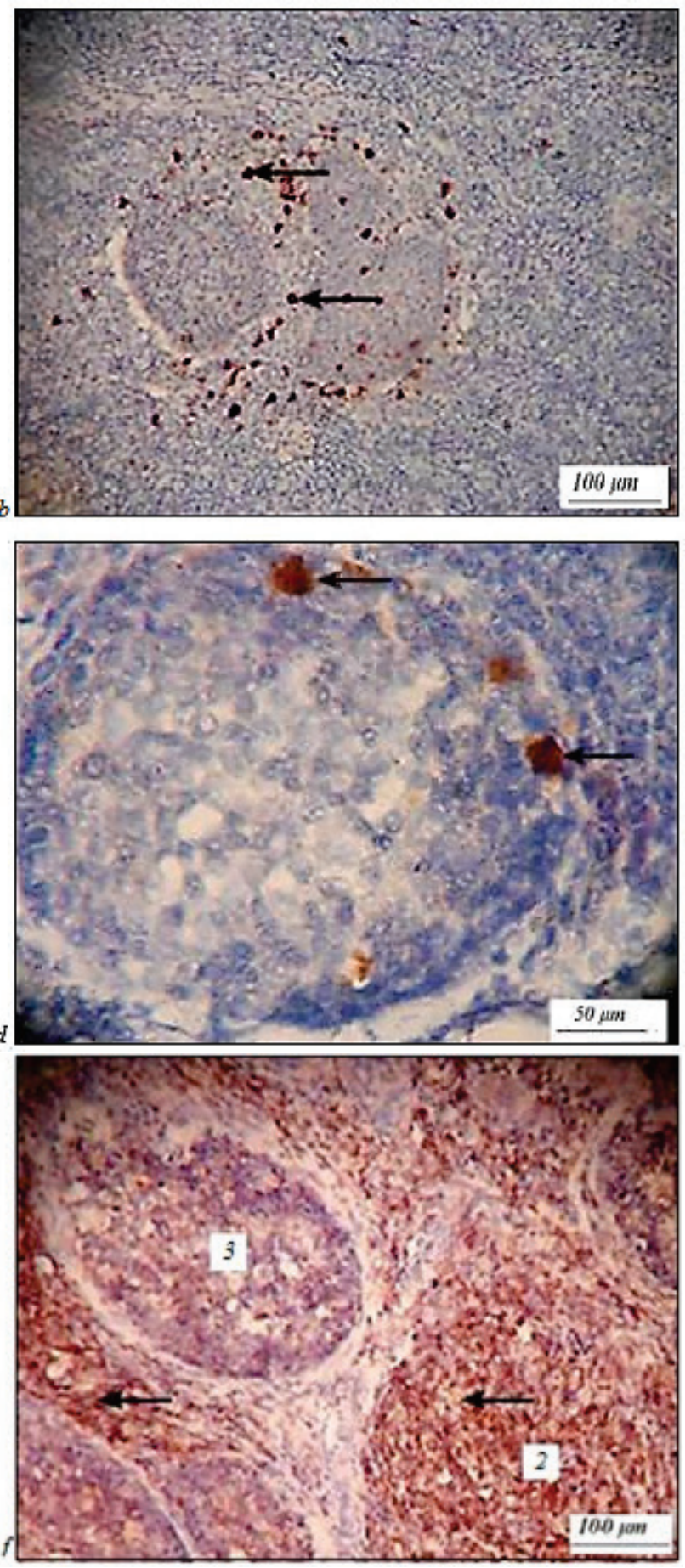

Fig. 1. Localization of lymphocytes in the esophageal tonsil of chickens (arrows): CD4+ lymphocytes in the epithelium of the excretory duct, 180 days old $(a)$, and in the lymphoid nodules, 300 days old (b); CD8+ lymphocytes in lymphoid nodules, 180 days old $(c)$ and 300 days old (d);

CD20+ lymphocytes in the limphoid tissue 25 days old $(e)$ and 180 days old $(f)$ : 1 - esophageal gland; 2 - diffuse lymphoid tissue;

3 -lymphoid nodule; histopreparations with the use of monoclonal antibodies; Mayers hematoxylin staining

\section{Discussion}

The tunica mucosa of the tubular organs of the digestive, respiratory, urinary and reproductive systems is under constant threat of penetration of various pathogens. Therefore, lymphoid tissue associated with tunica mucosa (mucosa-associated lymphoid tissue, MALT) plays an important role in immune control and immunoregulation. More than $50 \%$ of the body's lymphoid tissue is associated with this tunica and about $70 \%$ of all lymphocytes are localized in it (Jeurissen et al., 1989). Regardless of the pathway of antigen penetration into the body, they eventually interact with lymphoid tissue and initiate adaptive immune responses. The lymphoid tissues of the tunics mucosa are functionally interconnected, therefore, the contact of the immunogen with the tunica mucosa of a certain organ often leads to the formation of an immune response to it in other organs. 
The composition of the mucosa-associated lymphoid tissue includes intraepithelial lymphocytes, diffuse lymphoid tissue, separate and group lymphoid nodules (Cesta, 2006). Immunological tolerance of the lymphoid tissue of the digestive canal organs is necessary to avoid harmful inflammatory immune reactions against proteins in the feed (oral tolerance) and commensal microflora. It occurs due to suppression of both cellular (for example, delayed-type hypersensitivity) and humoral (antibody production) immune response (Ahluwalia et al., 2017).

Immunohistochemical methods using monoclonal antibodies are used to identify certain types of cells and substances synthesized in them. These methods are based on antigen-antibody reactions. To date, a nomenclature of antigenic marker receptors has been developed, designated by the symbol CD, which stands for cluster, group label of marker, anti- genic receptors or as a cluster of differentiation. It became possible with its help to immunophenotype lymphocytes in normal conditions and in various pathological conditions of the body (Panikar, 2015).

In the morphology of animals, immunohistochemical studies were carried out on the central and peripheral organs of hematopoiesis and immune defense of domestic pigs at the early stages of the postnatal period of ontogenesis (Panikar, 2015), and were also used to study the morphology of chicken organs in infectious bronchitis (Guralska, 2017) and diagnose circovirus infection in pigs (Havrylina \& Evert, 2016).

To determine the location and quantitative indicators of cell subpopulations of lymphocytes in the esophageal tonsil of chickens and Meckel's diverticulum of ducks, we used monoclonal antibodies with markers $\mathrm{CD} 4+, \mathrm{CD} 8+$ and $\mathrm{CD} 20+$
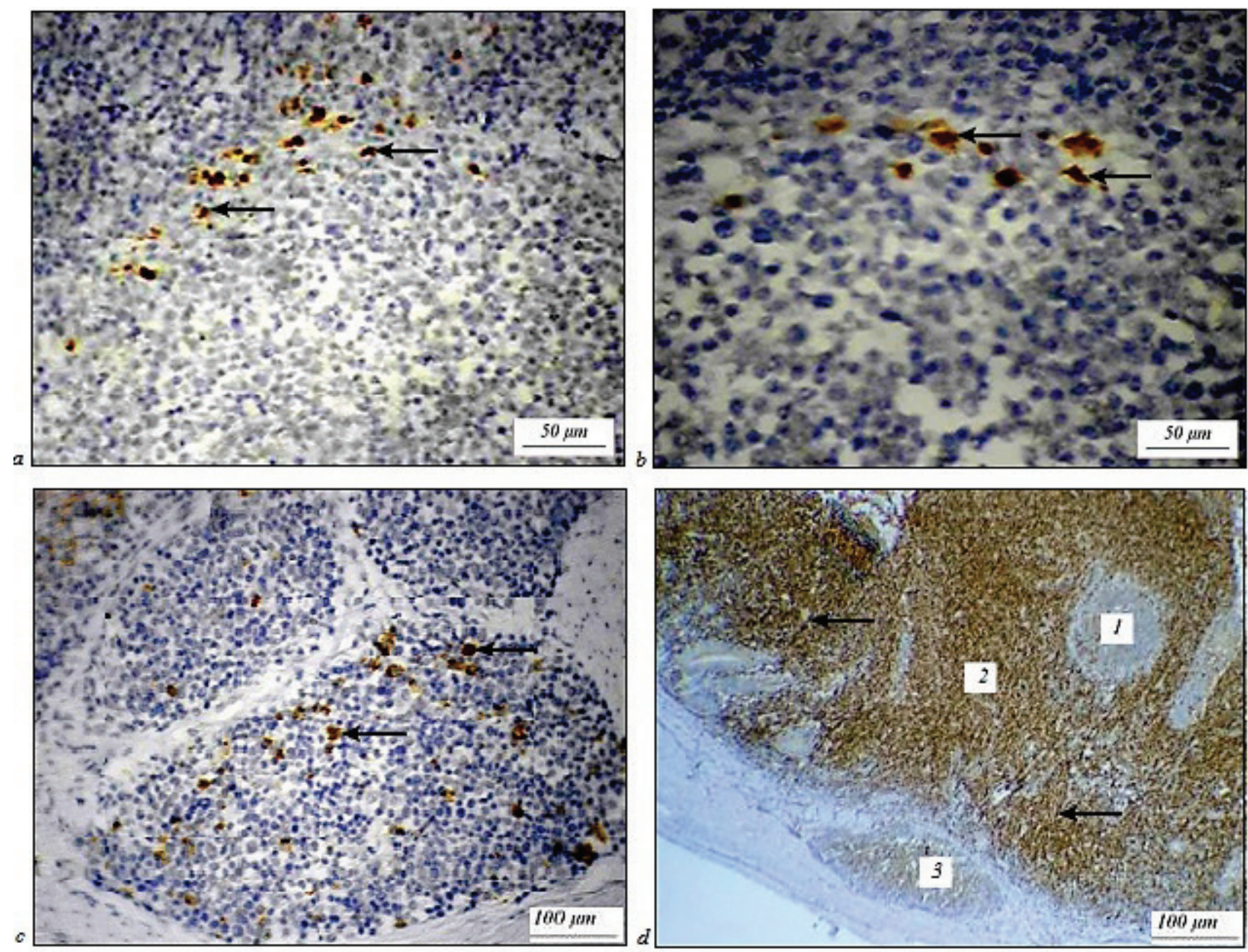

Fig. 2. Localization of lymphocytes in the Meckel diverticulum of ducks (arrows): CD4+ lymphocytes in the lymphoid nodule, 30 days old (a); CD8+ lymphocytes in lymphoid nodules, 30 days old $(b)$ and 150 days old $(c)$.; CD20+ lymphocytes in lymphoid tissue, 180 days old $(d)$ : 1 -lymphoid nodule of the tunica mucosa; 2 -diffuse lymphoid tissue; 3 -lymphoid nodule of the tunica muscularis; histopreparations with the use of monoclonal antibodies; Mayers hematoxylin staining

CD4 is a membrane glycoprotein, a coreceptor in the activation of T-cells of restricted class II of the main histocompatibility complex (major histocompatibility complex, MHC) (Knowles, 2000; Naeim et al., 2018). The CD4+ marker is associated with helper, inductive activity of T-lymphocytes. With the help of a specific receptor, T-helpers analyze the information provided by antigen-presenting cells, that is, they analyze the foreignness of the antigen. Stimulated T-helper cells produce a wide range of immunocytokines, with the help of which they control the biological activity of cells involved in the immune response. They induce the conversion of B-lymphocytes into plasma cells, increasing the synthesis of antibodies by one or two orders of magnitude (Nakamura et al., 2003; Kotsyumbas et al., 2014). CD4 is the primary receptor for HIV retroviruses. CD4 is expressed by a significant proportion of thymocytes (80-90\%) and more than $50 \%$ of peripheral blood T cells (subtype of helpers / inducers)
(Knowles, 2000). Most thymocytes coexpress CD4 and CD8. Monocytes, macrophages and Langerhans cells express CD4. Most postthymic T cell neoplasms are CD4-positive (Naeim et al., 2018). Another type of T cell expresses the antigenic marker CD8+ - a cell surface glycoprotein that is involved in mediating intercellular interactions in the immune system (Knowles, 2000; Schepers et al., 2005; Laky et al., 2006). This molecule is found on cytotoxic / suppressor T lymphocytes and most thymocytes. Approximately $80-90 \%$ of thymocytes and $35-45 \%$ of peripheral blood lymphocytes express CD8. Cytotoxic cells, T-suppressors, are able to destroy the infected and malignant cells, providing the formation of immunological tolerance (Kotsyumbas et al., 2014). The T-killer analyzes the cells in the body and eliminates target cells by antibody-independent cellmediated cytotoxicity. For this purpose, it synthesizes a number of toxic substances: perforin, granzyme, granulisin. T-cytotoxic lymphocytes also 
provide the formation of T-cell immunological memory, delayed-type hypersensitivity, activation of macrophages, the development of immune inflammation (Panikar, 2015). As mentioned above, most thymocytes express CD8 together with CD4. NK cells subpopulation (natural killer) also expresses CD8 (Knowles, 2000; Jaffe et al., 2001).

The main marker used to identify B cells is CD20. It is an integral non-glycosylated membrane protein that plays a role in the development and differentiation of B lymphocytes into plasma cells (Knowles, 2000; Macardle \& Nicholson, 2002). CD20 is a molecule with limited cloning and is expressed on both inactivated and activated B-lymphocytes, but disappears before differentiation into plasma cells (Macardle \& Nicholson, 2002; Walport et al., 2008). Cells expressing the CD20+ marker are mature B-lymphocytes (Smith et al., 2012). The main trait of these cells is the presence of antigen-recognizing immunoglobulin receptors on their surface. After the interaction of the antigen with these receptors, B-lymphocytes differentiate into plasma cells, the main function of which is the production of immunoglobulins - antibodies. Antibodies are able to bind and neutralize antigens that have entered the body. B-lymphocytes are involved in the formation of humoral immunity, B-cell immunological memory and immediate-type hypersensitivity (Alitheen et al., 2010).

The presence of cells with markers CD4+, CD8+ and CD20+ in the esophageal tonsil of chickens and Meckel's diverticulum of ducks shows that in immune formations of the digestive organs under the influence of antigenic stimulation, lymphocytes differentiate into effector cells that cause specific immunity. Lymphocytes with the indicated markers were found in the tunica mucosa and tela submucosa of the esophageal tonsil, and in addition, in the tunica muscularis of the Meckel diverticulum of birds of different age groups. Also, lymphocytes with the CD20+ marker were observed in the superficial epithelium and the epithelium of the mucosal crypts of the Meckel diverticulum. CD4+ lymphocytes were recorded in the stratified squamous epithelium of the esophageal tonsil of chickens. CD8+ lymphocytes were found in the epithelium of immune formations of the digestive organs (Göbel et al., 2001). Due to the infiltration of the epithelium of the immune formations of digestive organs of birds by lymphocytes, it turns into lymphoepithelium (Davison, 2014). B-lymphocyte infiltration of follicle-associated epithelium promotes the differentiation of $\mathrm{M}$ cells from enterocytes, which occurs under the influence of lymphotoxin, which they produce (Debard et al., 2001). B-cells are located in the pockets of M-cells. This localization is ideal for meeting the antigens of the intestinal lumen and they significantly outnumber other types of potential antigen-presenting cells in these microcompartments of the intestinal immune formations, where dendritic cells are virtually absent (Yamanaka et al., 2001).

The content of cells with markers CD4+, CD8+ and CD20+ is somewhat predominant in diffuse lymphoid tissue compared with secondary lymphoid nodules of both the esophageal tonsil of chickens and Meckel's diverticulum of ducks.

$\mathrm{CD} 20+$ lymphocytes predominated in the esophageal tonsil of chickens and Meckel's diverticulum of ducks by content among cells expressing different types of markers. Most of them were recorded in the lymphoid tissue of birds aged 180 days, that is, during sexual maturity, while the number of CD4+ and CD8+ lymphocytes was insignificant. A significant number of B-lymphocytes and a small number of CD4+ and CD8+ lymphocytes were recorded in the lymphoid tissue and other immune formations of the intestines of poultry (Davison, 2014). Populations of CD4+ and CD8+ lymphocytes in the cecal tonsils increase with age in chickens. The number of CD8+ lymphocytes was greater than CD4+ in 2-week-old chickens (Del Moral et al., 1998). A significant content of $\mathrm{CD} 20+$ lymphocytes in the cecum tonsils of chickens after vaccination and in infectious bronchitis was observed by Guralska (2017).

\section{Conclusions}

The humoral and cellular part of the immunity of the esophageal tonsil and Meckel's diverticulum of poultry is provided by T- and Blymphocytes and their subpopulations. Subpopulations of T-lymphocytes $\mathrm{CD} 4+$ and CD8+ are responsible for the cellular link of immunity, and the population of B-lymphocytes CD20+, which synthesizes antibodies - for the humoral. Specified subpopulations of lymphocytes in the esophageal tonsil of ckicken and Meckel diverticulum of ducks were distributed in diffuse lymphoid tissue and secondary lymphoid nodules. The content of these cells in the diffuse lymphoid tissue was much higher than in lymphoid nodules. The esophageal tonsils of chickens and Meckel's diverticulum of ducks of all studied age groups contained the most lymphocytes with the marker CD20+ and much lower subpopulations of lymphocytes CD4+ and CD8+. This indicates that lymphocytes that provide humoral immunity prevail in the studied immune formations of the poultry digestive organs. The content of these cells changes with the increasing age of the bird. In the esophageal tonsil of chickens, its maximum value was recorded in birds aged 180 days, and in older chickens it decreased. In the Meckel's diverticulum of ducks, the content of CD20+ lymphocytes increased with age and reached its maximum values at the age of 180 days.

The conducted survey is a part of the Scientific-Research Work "Study of the development, macro- and microstructure of immune formations of crop and stomach of chickens", Ministry of Education and Science of Ukraine, state registration number $0106 \mathrm{U} 003870$ and "Study of the topography, structure and functional features of the immune formations of the stomach and intestines of ducks in the postnatal period of ontogenesis", Ministry of Education and Science of Ukraine, state registration number 0111U003688.

\section{References}

Ahluwalia, B., Magnusson, M. K., \& Öhman L. (2017). Mucosal immune system of the gastrointestinal tract: Maintaining balance between the good and the bad. Scandinavian Journal of Gastroenterology, 52(11), 1185-1193.

Alitheen, N. B., McClure, S., \& McCullagh, P. (2010). B-cell development: One problem, multiple solutions. Immunology and Cell Biology, 88(4), 445-450.

Avtandilov, G. G. (1990). Medicinskaja morfometrija [Medical morphometry]. Medicina, Moscow (in Russian).

Besoluk, K., \& Eken, E. (2001). The arterial supply of Meckel's diverticulum in geese (Anser anser domesticus). Journal Veterinary Medical Science, 63(12), 1343-1345.

Branton, S. L., Lott, B. D., Morgan, G. W., \& Deaton, J. W. (1988). Position of Meckel's diverticulum in broiler-type chichens. Poultry Science, 67(4), 677-679.

Casteleyn, D., Doom, M., Van den Broeck, W., Simoens, P., \& Cornillie, P. (2010). Locations of gut associated lymphoid tissue in the 3-month-old chicken: A review. Avian Pathology, 39(3), 143-150.

Cesta, M. F. (2006). Normal structure, function, and histology of mucosa-associated lymphoid tissue. Toxicologic Pathology, 34, 599-608.

Ciriaco, E., Perez Pinera, P., Díaz-Esnal, B., \& Laurà, R. (2003). Age-related changes in the avian primary lymphoid organs (thymus and bursa of Fabricius). Microscopy Research and Technique, 62(6), 482-487.

Davison, F. (2014). The importance of the avian immune system and its unique features. In: Schat, K. A., Kaspers, B., \& Kaiser, P. (Eds). Avian immunology. Academic Press, London. Pp. 1-9.

Debard, N., Sierro, F., Browning, J., \& Kraehenbuhl, J.-P. (2001). Effect of mature lymphocytes and lymphotoxin on the development of the follicle-associated epithelium and M cells in mouse peyer's patches. Gastroenterology, 120(5), 1173-1182.

Del Moral, G. M., Fonfría, J., Varas, A., Jiménez, E., Moreno, J., \& Zapata, A. G. (1998). Appearance and development of lymphoid cells in the chicken caecal tonsil. The Anatomical Record, 250, 182-189.

Dishluk, N. V., \& Orlova, A. V. (2017). Osoblyvosti budovy stravokhodu ta yoho imunnykh utvoren' perepeliv [Structural features of esophagus and its immune formations in quails]. Scientific Messenger of Lviv National University of Veterinary Medicine and Biotechnologies named after S. Z. Gzhytskyj, 77(19), 3-6 (in Ukrainian).

Donmez, H. H., Eken, E., Besoluk, K., \& Sur, E. (2012). The histological characteristics and localization of ACP and ANAE positive lymphocytes in the oesophageal tonsil of the duck (Anas platyrhynchos). Avian Biology Research, 5(1), 11-15.

Fellah, J. S., Jaffredo, T., Nagy, N., \& Dunon, D. (2014). Development of the avian immune system. In: Schat, K. A., Kaspers, B., \& Kaiser, P. (Eds.). Avian immunology. Academic Press, London. Pp. 45-63.

Göbel, T. W., Kaspers, B., \& Stangassinger, M. (2001). NK and T cells constitute two major, functionally distinct intestinal epithelial lymphocyte subsets in the chicken. International Immunology, 13(6), 757-762.

Gofur, M. R. (2020). Meckel's diverticulum in animals and birds: An immunopathoclinical perspective. Bangladesh Journal of Veterinary Medicine, 18(1), 1-12.

Goralsky, L. P., Khomich, V. T., \& Kononsky, O. I. (2015). Osnovy gistologichnoji tekhniky i morfofynctsionalni doslidzhennia u normi ta pry patologiji [Basics of 
histological technique and morphofunctional methods of researches in the norm and pathology]. Polissya, Zhytomyr (in Ukrainian).

Guralska, S. V. (2017). Immunohistochemistry of the organs of hemopoiesis and immunogenesis of chickens at infectious bronchitis. Veterinary Biotechnology, 31, $50-58$.

Havrylina, O. H., \& Evert, V. V. (2016). Metodychni osoblyvosti zastosuvannya imunohistokhimichnoyi diahnostyky tsyrkovirusnoyi infektsiyi svyney [Methodological features of application of immunohistochemical diagnostics of circovirus infection of pigs]. Problems of Zooengineering and Veterinary Medicine, 32(2), 294-301 (in Ukrainian).

Jaffe, E. S., Harris, N. L., Stein, H., \& Vardiman, J. W. (2001). Pathology and genetics. Tumors of Haematopoietic and Lymphoid Tissues. IARC Press, Lyon.

Jeurissen, S. H. M., Janse, E. M., Koch, G., \& De Boer, G. F. (1989). Postnatal development of mucosa-associated lymphoid tissues in chickens. Cell and Tissue Research, 258, 119-124.

Karadag, S. E., Altunay, H., Kurtdede, N., \& Bakir, B. (2015). The structure of bursa of fabricius in the long-legged buzzard (Buteo rufinus): Histological and histochemical study. Acta Veterinaria, 65(4), 510-517.

Kaspers, B., \& Göbel, T. W. F. (2016). The avian immune system. In: Ratcliffe, M. J. H. (Ed.). Encyclopedia of immunobiology. Elsevier Ltd. Vol. 1. Pp. 498-503.

Knowles, D. M. (2000). Neoplastic hematopathology. 2nd ed. Lippincott Williams \& Wilkins, Philadelphia.

Kotsyumbas, I. Y., Zhyla, M. I., Shkodyak, N. V., Sobodosh, S. Y., \& Martynyk, S. Y. (2014). Retseptory poverkhnevykh struktur imunokompetentnykh klityn u tvaryn. Suchasni metody yikh vyznachennya [Receptors of surface structures of immunocompetent cells in animals. Modern methods of their determination]. Scientific and Technical Bulletin of the Institute of Animal Biology and the State Research Control Institute of Veterinary Drugs and Feed Additives, 15(2), 349-355 (in Ukrainian).

Koutsos, E. A., \& Klasing, K. C. (2014). Factors modulating the avian immune system. In: Schat, K. A., Kaspers, B., \& Kaiser, P. (Eds.). Avian immunology. Academic Press, London. Pp. 299-313.

Kovtun, M. F., \& Kharchenko, L. P. (2005). Limfoidnyye obrazovaniya pishchevaritel'noy trubki ptits: Kharakteristika i biologicheskoye znacheniye [Lymphoid formations of the digestive tube of birds: Characteristics and biological significance]. Vestnik Zoologii, 39(6), 51-60 (in Ukrainian).

Laky, K., Fleischacker, C., \& Fowlkes, B. J. (2006). TCR and Notch signalingin CD4 and CD8 T-cell develjpment. Immunological Reviews, 209, $274-283$.

Logvinova, V. V., Oliyar, A. V., \& Lieshchova, M. A. (2020). Formuvannya imunnykh struktur tonkoyji kyshky muskusnykh kachok (Cairina moschata) [Formation of immune structures in small intestine of Muscovy ducks (Cairina moschata)]. Theoretical and Applied Veterinary Medicine, 8(1), 50-55.
Macardle, P. J., \& Nicholson, I. C. (2002). CD20. Journal of Biological Regulators and Homeostatic Agents, 16(2), 136-138.

Nagy, N., Igyártó, B., Magyar, A., Gazdag, E., Palya, V., \& Olah, L. (2005). Oesophageal tonsil of the chicken. Acta Veterinaria Hungarica, 53(2), 173-188.

Nakamura, K., Yube, A., Miyatake, J. C., \& Cambier, M. (2003). Hirashima involvement of CD4 D3-D4 membrane proximal extracellular domain for the inhibitory effect of oxidative stress on activation-induced CD4 down-regulation and its possible role for T cell activation. Molecular Immunology, 39, 909-921.

Olah, I., \& Glick, B. (1984). Meckel's diverticulum. I. Extramedullary myelopoiesis in the yolk sac of hatched chickens (Gallus domesticus). The Anatomical Record, 208, 243-252.

Oláh, I., Nagy, N., \& Vervelde, L. (2013). Structure of the avian lymphoid system. In: Schat, K. A., Kaspers, B., \& Kaiser, P. (Eds.). Avian immunology. Academic Press, London. Pp. 11-44.

Panikar, I. I. (2015). Imunohistokhimichna kharakterystyka subpopulyatsiy limfotsytiv orhaniv imunnoyi systemy svyney na rannikh etapakh postnatal'noho periodu ontohenezu [Immunohistochemical characteristics of subpopulations of lymphocytes of the immune system of pigs in the early stages of the postnatal period of ontogenesis]. Problems of Zooengineering and Veterinary Medicine, 30(2), 426-432 (in Ukrainian).

Polegenka, M. A. (2019). Analiz suchasnoho stanu vyrobnytstva produksiyi ptakhivnytstva $v$ Ukrajini [Analysis of the current state of production of poultry products in Ukraine]. Ekonomika i Derzhava, 3, 137-143 (in Ukrainian).

Rahman, M. L., Islam, M. R., Masuduzzaman, M., \& Khan, M. Z. I. (2003). Lymphoid tissues in the digestive tract of deshi chicken (Gallus domesticus) in Bangladesh. Pakistan Journal of Biological Sciences, 6, 1145-1150.

Samour, J. (2015). Avian medicine. 3rd ed. Mosby Ltd., Город.

Schepers, K., Arens, R., \& Schumacher, T. N. M. (2005). Dissection of cytotoxic and helper T cell responses. Cellular and Molecular Life Sciences, 62(23), 2695-2710.

Sharma, J. M. (1991). Overview of the avian immune system. Veterinary Immunology and Immunopathology, 30(1), 13-17.

Smith, P., MacDonald, T., \& Blumberg, T. (2012). Principles of mucosal immunelogy. Garland Science, New York.

Walport, M., Murphy, K., Janeway, C., \& Travers, P. J. (2008). Janeway’s Immunobiology. 7th ed. Garland Science, New York.

Yamanaka, T., Straumfors, A., Morton, H. C., Fausa, O., Brandtzaeg, P., \& Farstad, I. N. (2001). M cell pockets of human Peyer's patches are specialized extensions of germinal centers. European Journal of Immunology, 31, 107-117.

Yasuda, M., Kajiwara, E., \& Ekino, S. (2003). Immunobiology of chicken germinal center: I. Changes in surface Ig class expression in the chicken splenic germinal center after antigenic stimulation. Developmental and Comparative Immunology, 27(2), 159-166. 